\title{
Necessary and sufficient factors in employee downsizing? A qualitative comparative analysis of lay-offs in France and the UK, 2008-2013
}

\author{
Michel Goyer, Organisation, Work and Employment, Birmingham Business School \\ Ian Clark, Centre for Sustainable Work and Employment Futures and Department of \\ Management, University of Leicester \\ Shabneez Bhankaraully, Organization, Work and Employment, Birmingham Business \\ School \\ Human Resource Management Journal, Vol 26, no 3, 2016, pages 252-268
}

Embedded in the literature on financialization and institutional approaches, this study is an examination of the causal factors of employee downsizing in two institutionally dissimilar settings, France and the UK, using the fuzzy sets variant of Qualitative Comparative Analysis. The findings show that the roughly equivalent use of large-scale lay-offs in the two countries is coupled with strikingly different causal factors. Our argument suggests the importance of complex causation whereby employee downsizing reflects the growing influence of financial considerations in the governance of companies, but its diffusion across countries is shaped by different configurations of institutional arrangements.

Contact: Michel Goyer, Organisation, Work and Employment, Birmingham Business School.Email: m.goyer@bham.ac.uk

Keywords: complex causation; employee downsizing; financialization; fuzzy sets QCA; institutional investors; institutions; leverage; ownership structures

\section{INTRODUCTION}

$\mathbf{T}$

his article examines causal factors behind large-scale employee downsizing in two different settings, France and the UK, from 2008 to 2013. Our theoretically informed comparative study contributes to important debates in two literature sets: those on financialization and comparative institutionalism. Financialization refers to the increased importance of financial considerations in the governance of companies, which prioritizes the interests of investor-owners, which is shareholder value (van der Zwan, 2014). This greater prominence of finance is made possible by important structural developments in the global economy, most notably removal of controls on capital movements across borders and the growth in the financial assets of shareholder value driven funds. These developments have resulted in unprecedented amounts of capital chasing profitable investment opportunities (Engelen and Konings, 2010; see also Krippner, 2005). At firm level, financialization highlights how the ascendancy of shareholder value entails an important reorganization of resource allocation aimed at keeping stock prices high and returning cash flows to shareholders. In the context of investor and shareholder value, recourse to employee downsizing constitutes a popular strategy used by companies to generate resources that are then distributed to shareholders (Jacoby, 2005; Clark, 2013; Appelbaum and Batt, 2014).

Our second contribution is to the literature on comparative institutional analysis. Institutional approaches constitute mid-range theory that aims to illustrate how conflict over resources and strategic choices are mediated by the institutional setting in which they take 
place (Hall, 1986; Thelen and Steinmo, 1992). Institutional arrangements matter because they enable, and constrain, different firm-level actors (managers, shareholders and workers) in their competing claims over the allocation of resources and, more broadly, over the governance of the firm (Whitley, 1999; Campbell, 2004). That is, institutions structure power relations inside companies that, in turn, strengthen the ability of different actors to advance their interests against others with different preferences (Hall, 1986; Gourevitch and Shinn, 2005; see also Goergen et al., 2013 for downsizing). Incorporating institutional analyses into the study of employment relations is insightful in order to account for the diffusion of financialization, a highly redistributive phenomenon, across different countries.

Our argument, in respect of employee downsizing, centres on the necessity of situating HR strategies within a corporate context that incorporates both the priorities of financialization within firms and the importance of institutional diversity across national business systems. To effectively address this challenge, we incorporate into our analysis theoretical insights developed across the social sciences that highlight the importance of complex causation in understanding outcomes, such as the implementation of large-scale employee lay-offs (Ragin, 1987; Mahoney, 2004). From an ontological standpoint, our argument illustrates how the implementation of employee downsizing across national settings is not generated by the presence of one single cause applicable to all national business systems. Rather, downsizing occurs as the result of configurations of specific conditions that differ across national settings. The presence of institutional diversity, while not constituting an obstacle to the diffusion of shareholder value practices as correctly asserted by financialization approaches, provides revealing insights enabling us to assess which sets of conditions will be necessary and/or sufficient to generate a similar outcome, namely, employee downsizing, across institutionally different economies (Braumoeller, 2003; Goyer, 2011: 106-128).

The diffusion of financial considerations across national settings is shaped by the extent to which institutional arrangements enable actors to implement, or resist, employee downsizing. In the institutionally constrained context of the French economy, the presence of several 'conducive' factors is required for large-scale lay-offs to take place. In the institutionally permissive context of the UK economy, in contrast, the implementation of employee downsizing schemes will be easier as reflected by the presence of less demanding configurations of specific factors. Drawing from the literature on comparative corporate governance (Roe, 2000; Gourevitch and Shinn, 2005; Atanassov and Kim, 2009; Gospel and Pendleton, 2014), we develop our theoretical framework by examining the impact of three firm-level financialized variables on the implementation of large-scale downsizing schemes: financial leverage; categories of institutional investor; and ownership structures of companies.

This article is structured as follows. The first part looks at two theoretical perspectives that provide important contextual insights for the study of employee downsizing: financialization and institutional approaches. Part two integrates financialization and institutional approaches into our framework of complex causation. This integration leads to a complex and comprehensive understanding of the increased prominence of financial considerations in the governance of companies across different institutional settings. We also outline how Qualitative Comparative Analysis (QCA) as a research method best captures notions of complex causation. Part three presents the foundations of the QCA methodology. Part four reports on our data sample. Part five reveals our empirical findings and part six contains a discussion and conclusion on our findings and the contribution of our research to theory building. 
Financialization constitutes an important theoretical perspective that provides key insights for the investigation of employee downsizing, an increasingly prevalent phenomenon in contemporary capitalism (Clark, 2009; Thompson, 2011). The prominence of financial considerations in the governance of companies has been made possible by important structural changes in the global economy: the liberalization of capital flows across borders and the growth in the financial assets of shareholder value driven funds - especially those based in the UK and in the US (Engelen and Konings, 2010). As a result, an unprecedented amount of capital is moving across international financial markets in search for liquid and profitable investment opportunities. At the firm level, financialization refers to the ascendancy of shareholder value as the guiding star for firm strategy that prioritizes the interests of shareholders at the expense of other actors in the corporation, most notably employees, thereby resulting in a major redistribution of wealth (see also Gourevitch and Shinn, 2005; Jacoby, 2005; van der Zwan, 2014). In liberal market economies, the unbridled pursuit of shareholder value means that new financial objectives, for example, high stock prices and maximizing the release of cash flows to shareholders, are being pursued at the expense of other goals - and very often via the breach of implicit contracts with employees (Appelbaum et al., 2013; Appelbaum and Batt, 2014).

The implementation of employee downsizing is central in this redistributive process. Shareholder value driven objectives are often secured by the implementation of corporate policies that allocate resources away from employees - most notably dividend payouts, a focus on core competencies, share buybacks and the introduction of a financial performance matrix such as return on equity (Kahan and Rock, 2007; Brav et al., 2008). Yet, the implementation of employee downsizing schemes does not contribute to the innovative capabilities of the firm as revenues generated from these lay-offs are not reinvested. The (potential) productivity gains of 'financialized' firms are appropriated by shareholder value driven investors at the expense of retained profit for further investment in innovation (Jacoby, 2005; Appelbaum and Batt, 2014; Goergen et al., 2014). Therefore, as highlighted in this journal, incorporating financialization as a new structural development into the analysis of employment relations is paramount given the traditional focus of HRM approaches around concepts of high performance work systems that neglect the increased influence of finance (Thompson, 2011: 361).

A conceptual challenge for the theorization of financialization, however, is to account for the diffusion of this new business model across institutionally dissimilar business systems. By (correctly) emphasizing structural developments as crucial factors in the prominence of financial considerations, these approaches place less emphasis on the contingent character of their introduction in specific contexts. Because of its heavily redistributive character, the diffusion of financialization across countries is not a neutral process but one characterized by conflict where intricacies therein remain to be investigated (Gourevitch and Shinn, 2005; Goyer, 2011). For instance, two studies on downsizing in non-liberal market economies, Munoz-Bullon and Sanchez-Bueno (2014) on Spain and Ahmadjian and Robinson (2001) on Japan, illustrate the importance of institutional isomorphic pressures that encourage companies to implement employee downsizing whenever other 'leading' firms adopt this practice. That is, the introduction of employee downsizing as a shareholder value practice in these two economies raised issues of institutional legitimacy as companies felt comfortable in implementing employee downsizing schemes only as followers. As recently 
noted, therefore, an important challenge is to understand how the increased prominence of financialization translates into workplace outcomes across different business systems (Thompson and Cushen, 2015).

A second theoretical perspective for the study of employee downsizing is the literature on comparative institutional analysis. Institutional approaches are conceptualized as mid-level variables, as distinct from macro-structures, that act as mid-range theory (Hall, 1986; Thelen and Steinmo, 1992). Institutionally based scholars do not advance the notion that only institutions matter for outcomes. Rather institutional analyses aim to account for how conflict over resources, and strategic choices by actors are mediated by the institutional setting in which they take place (Whitley, 1999; Campbell 2004). Institutional analyses are also often built around a specific research design, namely, how the presence of institutional differences account for observed variations in an outcome variable of interest (Dobbin, 1994). From a methodological perspective, therefore, institutional approaches aim to explain variations within a class of phenomenon based on the presence of institutional differences that, in turn, makes it difficult to conceptualize how and why exogenous structural developments occur (Krippner, 2005).

Institutional approaches are, however, better suited to explain the diffusion of financialization across national settings. The redistributive character of the financialization process serves as a reminder that the corporation remains a contested entity with different actors making divergent claims regarding its governance (Whitley, 1999; Campbell, 2004). In this context, the transposition of the preferences of actors into outcomes, and their ability to defend their interests against other actors with opposing preferences, constitutes a process that is shaped by institutional arrangements that structure power relations (Hall, 1986; Dobbin, 1994). For instance, a decision to introduce employee downsizing schemes might take place at the firm level but does not occur in an institutional vacuum. Institutional arrangements characterized by strong employment protection enable workers to better defend their interests, most notably by limiting the managerial prerogative to adjust employment levels via strategies of external flexibility (Goergen et al., 2013; OECD, 2013). The institutions governing job security shape managerial ability to determine who is recruited and laid off. In turn, institutional constraints placed on the managerial prerogative to use labour reduce their ability to redistribute resources to shareholders (Roe, 2000). As a result, differences in institutional arrangements across national settings provide employees with diverging capabilities to moderate the impact of structural changes in the global economy against other actors, most notably shareholders, with different preferences regarding the governance of the corporation.

The case selection of France and the UK is well suited for integrating the insights of financialization and institutional approaches. In terms of research design, these two countries constitute most dissimilar systems as they sit at opposite ends of the European institutional spectrum regarding employment protection. The UK is characterized by institutional arrangements that place few restrictions on the managerial prerogative to dismiss employees. Compared with other European countries, the UK maintains only weak employment protection as measured by the costs of hiring new employees, size of severance payments, notice period for the initiation of collective dismissal procedures and the legal recourse of employees against collective dismissals (Goergen et al., 2013; OECD, 2013). The heightened managerial ability to reorganize the workplace is further supported by now embedded Thatcher era and successive pieces of legislation that have reduced trade union power by imposing secret ballots to support industrial action, placed restrictions on secondary picketing and strongly diluted the constraining character of pre-job and post-job entry agreements for union membership (Howell, 2005; Davies and Freedland, 2007). 
France, in contrast, is characterized by restrictive institutional arrangements over the regulation of job security for both open-ended contracts and atypical employment. Employment protection for open-ended contracts is comparatively strong by European standards when strength is measured by the size of severance payments, notice period for the initiation of collective dismissal procedures and the legal recourse available to employees in cases of collective dismissal (Gumbrell-McCormick and Hyman, 2006; OECD, 2013). The French economy also exhibits extremely strict regulatory enforcement in the area of atypical employment, namely, fixed-term contracts and part-time jobs (Venn, 2009). The use of part-time contracts and fixed-term contracts is limited to specific situations, mainly the replacement of an employee who is absent and for unexpected increases in activities.

The selection of France and the UK provide informative settings to investigate the insights associated with integrating financialization and institutional approaches - the former focusing on the emergence of structural changes in the global economy that heightened financial considerations in the governance of the firm; the latter illuminating how these new pressures spread across national settings. The expectation of financialization approaches is that the use of employee downsizing will be prominent in the governance of French and UK companies, that is, two institutionally dissimilar business systems. From the perspective of institutional approaches, by contrast, the diffusion of financial considerations in the form of employee downsizing, a highly redistributive process, is likely to be more contested in France than in the UK given the presence of institutional differences in the use of lay-offs (Gourevitch and Shinn, 2005; Goergen et al., 2013).

\section{THEORY AND PROPOSITIONS: A QUALITATIVE COMPARATIVE ANALYSIS OF EMPLOYEE DOWNSIZING IN FRANCE AND THE UK}

Our investigation focuses on the causal factors of large-scale lay-offs in France and the UK between 2008 and 2013. From an ontological standpoint, our argument is embedded in the literature on complex causation whereby important events are not generated by the presence of one cause alone, but occur as the result of different configurations of specific conditions (Ragin, 1987; Hall, 2003; Thelen and Mahoney, 2015). Sensitivity to complex and historical specificities is unlikely to be achieved by explanations that seek to identify the direct effects of a particular independent variable across dissimilar contexts (Mahoney, 2004). Stand-alone explanations invariably fail to capture processes of causal complexity - especially in the context of diffusion across different business systems (Hall, 2003).

Our investigation is based on the use of the QCA, the technique developed by Ragin (2000) to capture instances of causal complexity. ${ }^{1}$ Built on the logic of Boolean algebra, a key strength of QCA is its combination of the strengths of both case-oriented research and quantitative research to capture how economic and social outcomes are generated by a configuration of factors, that is, complex causation (Schneider and Wagemann, 2012). The analysis of causal complexity via the QCA method differs from statistical techniques as the impact of hypothesized independent variables on the dependent variable is not additive, but rather cumulative and interdependent (Ragin, 1987; Mahoney, 2004). The QCA technique captures two forms of causal complexity: conjunctural causation and equifinality.

Conjunctural causation refers to how interactions among different factors generate a specific outcome that would not occur without the presence of all of these interacting factors $(x 1+x 2+\ldots x N \rightarrow y)$. In other words, individual hypothesized independent variables are necessary but not sufficient to produce a specific outcome (Ragin, 2000; Mahoney, 2004). Necessary but not sufficient conditions for downsizing illustrate that 
some specific outcomes are relatively more difficult to achieve because the occurrence of the value of interest on the dependent variable is contingent upon the presence of all hypothesized independent variables (Hall, 2003).

Equifinality, in contrast, captures the presence of different but functionally equivalent, and thus non-competing paths that secure a similar outcome $(\mathrm{x} 1$ or $\mathrm{x} 2$ or $\ldots \mathrm{xN} \rightarrow \mathrm{y})$ (Ragin, 1987; Mahoney, 2004). In other words, hypothesized independent variables are sufficient but not necessary to produce a specific outcome. Sufficient but not necessary conditions for downsizing illustrate that some specific outcomes are relatively easier to achieve given the presence of several alternative paths to the occurrence of a similar outcome (Braumoeller, 2003). Functionally equivalent paths reflect the presence of a greater range of possible courses of actions by which shareholder value practices spread across business systems.

The use of complexity provides a comprehensive understanding of important phenomenon in social sciences. Theoretically, our application of complex causation allows us to illustrate how institutional arrangements shape the diffusion of financialization considerations across national business systems. Social science research increasingly relies on the notion of causal complexity to explain important outcomes but invariably fails to conceptualize the specific types of complexity required to generate a specific outcome in terms of the uneven distribution of necessary/sufficient conditions across settings (Mahoney, 2008). By building on this observation, we argue that settings characterized by extensive institutional constraints, such as those in France, will require the presence of a greater number of 'supporting' factors for downsizing to occur. The incorporation of financial considerations in the governance of French companies is characterized by the presence of conjunctural causation whereby several factors interact together in order to overcome institutional barriers and by the presence of a highly limited number, and constraining, set of scenarios of substitutability, thereby illustrating that employee downsizing is difficult to implement in France. In settings characterized by institutional permissiveness, such as the UK, our expectation is that the implementation of employee downsizing will result from significantly less demanding sets of factors. Therefore, our argument emphasizes how the presence of institutional diversity in employment protection in France and the UK points to different types of managerial challenge when financial considerations, such as the implementation of large-scale lay-offs, are introduced into the strategic governance of companies. That is, different types of complex causation (necessary/sufficient conditions) will be needed to generate employee downsizing across institutionally dissimilar national business systems.

We develop our conceptual framework empirically by testing the causal effect of three financialized variables from the literature on comparative corporate governance that are central to employee downsizing: financial leverage; categories of investors; and ownership structures of companies (Roe, 2000; Gourevitch and Shinn, 2005; Brav et al., 2008; Atanassov and Kim, 2009; Gospel and Pendleton, 2014).

\section{Debt/financial leverage}

An important variable in empirical studies of employee downsizing is leverage (Cascio, 1993; Datta et al., 2010). While the level of debt is not necessarily an indicator of poor performance, it does raise two issues with implications for the undertaking of employee downsizing across national business systems. The first one relates to the governance of the firm. High indebtedness could lead to a loss of control to creditors and/or increase the risks of bankruptcy (Bruslerie and Latrous, 2012). As a result, high debt generates 
strong incentives for corporate insiders, controlling shareholders and managers alike, to confront employees in order to extract concessions for avoiding the occurrence of these two scenarios (Bronars and Deere, 1991). In situations of high indebtedness, the bargaining power of employees might be reduced. Empirical studies across a range of institutionally dissimilar national business systems, characterized by varying regulations of employment termination, have documented that the implementation of large-scale layoffs is undertaken by companies with more extensive debt loads as compared with other domestic firms (Atanassov and Kim, 2009). In particular, strong employment protection is less effective in preventing large-scale lay-offs in situations of high leverage (Atanassov and Kim, 2009).

The second issue associated with debt is the changed funding strategy of banks in many advanced capitalist economies, including France and the UK, that, in turn, impact on their ability to provide debt finance and roll over existing debt (Hardie et al., 2013). An important, and traditional, function of banks is to serve an intermediary between household savers and non-financial corporations, which is to issue loans that are financed by relatively stable customer deposits. As a result of a series of changes that took place since the mid/late 1990s, by contrast, commercial banks have developed new series of business activities that involves repacking pools of loans into tradable instruments, that is, securitization. Moreover, these new banking activities are no longer exclusively financed by customer deposits, but entails recourse to borrowing from investors and other banks. Thus, banks increasingly faced a funding gap whereby customer deposits do not cover their lending activities. Prior to the advent of the 2008 financial crisis, the funding gap of commercial banks in France and the UK was significantly important, the two highest among the G5 countries, and exceed the 10-per cent figure (Hardie et al., 2013). ${ }^{2}$ Moreover, this funding gap was financed by relatively short-term sources from wholesale markets: French banks covered their funding gap via issue of short-term debt securities (Howarth, 2013) while UK banks exhibited strong reliance on borrowing from short-term driven inter-bank and commercial paper markets (Hardie et al., 2013). The fragility of the funding activities of banks, in turn, has led to a severe tightening of their lending activities between 2008 and 2013 because of the cost and availability of funding, that is, the credit crunch, as large commercial banks in the two countries scrambled to lower their reliance on external sources of funding (The Economist, 2013; Hardie et al., 2013: 9). Non-financial companies with high leverage might face difficulties to refinance themselves given the financing constraints faced by commercial banks.

We investigate the impact of leverage on the undertaking of employee downsizing in France and the UK in the overall context of the credit crunch, while their respective regulation of employment dismissals is still characterized by significant institutional differences. Greater financial leverage enhances the bargaining position of management because the credible threat of bankruptcy or significant plant closures makes it easier to extract concessions from employees. This is likely to be an important factor in France given the presence of extensive institutional constraints that make it difficult to implement employee downsizing as an offensive strategic tool aimed at enhancing shareholder value. Thus, our expectation is that high financial leverage will constitute a necessary condition for the introduction of employee downsizing programmes in France (Proposition 1).

By contrast, the UK exhibits comparatively weak employment protection where the governance of companies is shaped by the presence of institutional arrangements that heighten managerial ability to introduce downsizing in both favourable and adverse macroeconomic conditions (OECD, 2013). Thus, our expectation is that high financial leverage/debt, which increases the bargaining power of management vis-à-vis their employees, will not be needed 
and, therefore, will not constitute a necessary condition for the introduction of employee downsizing programmes in the UK (Proposition 2).

\section{Categories of investors and employee downsizing}

Financialized investors are important actors in contemporary capitalism, which bring with them negative consequences for employment stability (Jacoby, 2005; van der Zwan, 2014: 114-119). However, employee downsizing cannot be simply captured by the rise in practices emblematic of shareholder value in the strategic governance of the firm; it is, rather, contingent on specific categories of investors. Different categories of shareholder value driven investors hedge funds, private equity, mutual funds, pension funds and sovereign wealth funds constitute sub-groups with different incentives. In turn, these sub-groups are governed by particular internally defined rules - that impact differentially on employment relations (Gospel and Pendleton, 2014: 1-26).

Financialized investors - hedge funds and private equity funds - constitute the most disruptive categories of investors for employment relations. Because of internal rules on trading and managerial remuneration schemes, these investors are driven by performance goals, not by diversification concerns, as fund managers are incentivized to secure the maximum possible absolute returns, not just achieve targeted mandated minimum returns (Goyer, 2006). Fund manager compensation derives from the amount of assets under management (1-2 per cent) and, to a substantial extent, from incentive fees (usually 20 per cent of profits) once a defined hurdle rate of return has been achieved. These more aggressive investor-owners are also characterized by short-term horizons, especially hedge funds, as highlighted by their higher turnover rates of equity holding, and are more likely to target undervalued foreign companies whose market capitalization may increase following the implementation of corporate restructuring policies (Brav et al., 2008). For these investors, shareholder activism is ex ante; they select companies on the basis that their involvement as equity owners will trigger changes in corporate policies (Kahan and Rock, 2007).

Mutual funds, on the other hand, constitute an intermediary category of investor-owner whose economic incentives are very similar to those of 'aggressive' hedge funds but whose mode of shareholder activism, if occurring at all, is ex post (Brav et al., 2008). Mutual fund managers are encouraged to surpass financial benchmarks (relative performance) as a result of variable pay incentives and greater liquidity concerns from savers whose investments are redeemable at any time. Finally, pension funds and sovereign wealth funds constitute longterm investor-owners with low turnover rates of portfolio stocks, and whose investment strategies and mode of governance are the least disruptive to employment relations (Goyer, 2011: 51-70). Their long-term investment strategy results in risk diversification through investment in a large number of companies - although pension funds are outsourcing part of the management of their assets to more active investors. Moreover, financial incentives for fund managers are less imperative indicating that the size of the pool is limited by the current cohort of retirees.

In summary, investment funds exhibit variations in incentive sets for fund manager remuneration, length of investment horizons and the extent to which the investment strategy is driven by performance concerns versus risk diversification. Our expectation is that the presence of pension funds and sovereign wealth funds, that is, investment funds, which themselves are less financialized, will not constitute either a necessary or a sufficient condition in both France and the UK for the implementation of lay-off schemes (Proposition 3). The mere presence of hedge funds and private equity investors, on the other hand, is insufficient to accurately predict outcomes across business systems. In France, aggressive rentier investor- 
owners face significant institutional constraints regarding their ability to secure the implementation of large-scale downsizing. Our expectation is that the sole presence of hedge funds, mutual funds and private equity investors will not constitute a sufficient condition in itself for the introduction of employee downsizing programmes in the institutionally constraining context of France (Proposition 4).

\section{Ownership structure of companies}

The ownership structure of listed companies has been identified as a central variable in the literature on comparative corporate governance in relation to the ability of managers to meet the demands of investors and implement shareholder value practices (Roe, 2000; Gourevitch and Shinn, 2005). In liberal market economies, the ownership structure of listed companies is dispersed with shares being widely distributed. Non-liberal market economies, by contrast, are characterized by the presence of controlling shareholders with a large equity stake that enable them to shape the strategic direction of the firm. Variations in ownership structures matter for the implementation of shareholder value practices because the presence of a concentrated equity owner substantially reduces the effectiveness of shareholder activism by investors (Kahan and Rock, 2007; Brav et al., 2008). Put simply, institutional investors, who acquire only 5-20 per cent of the equity stake of listed companies as minority shareholders, can be outvoted by the large controlling owner.

Building on this literature, we investigate whether, and how, the presence of ownership diffusion will be a favourable factor for the implementation of employee downsizing schemes. The ability of hedge funds and private equity funds to promote and secure employee downsizing could be significantly strengthened in the context of ownership diffusion because there is no insider owner with a controlling equity stake that could outvote them. In the presence of ownership concentration, in contrast, a large insider can always outvote aggressive shareholder activism. In the institutionally permissive context of the UK, we expect the presence of ownership diffusion to enable short-term investors to secure the implementation of employee downsizing. Thus, our expectation is that employee downsizing in the UK will not occur in the presence of ownership concentration (Proposition 5). In the French case, in contrast, the joint presence of financialized investors and ownership diffusion will not constitute a sufficient path by which employee downsizing occurs (Proposition 6). Leverage still matters in France (Proposition 1).

\section{METHODS}

We adopt the fuzzy sets variant of QCA (fsQCA) because it enables our variables to be captured through graded, but non-dichotomous, membership within a scale of 0 (full nonmembership) to 1 (full membership) (Ragin, 2000; Schneider and Wagemann, 2012). Dependent and independent variables are not always best measured in a dichotomous form, but are characterized by differences both in degrees and kinds. Hedge funds and sovereign wealth funds constitute categories of institutional investors that are located at each extreme of the spectrum regarding the extent to which they are potentially disruptive to employment relations but other categories of shareholders, such as mutual funds, are not. Therefore, it is appropriate to code variables along a spectrum rather than in a dichotomous manner.

The use of the QCA set-theoretic method is associated with the coding of variables to the (relative) extent to which they fit into a 'set' or not with a defined concept of interest - employee downsizing in this article. This coding process is called calibration. In the earlier example, we investigate the extent to which institutional investors have incorporated the priorities of 
financialization because we hypothesize that a heightened focus on shareholder value results in higher recourse to employee downsizing. Therefore, hedge funds are calibrated with a fuzzyset membership of 1 compared with $0.8,0.6,0.3$ and 0.2 for private equity funds, mutual funds, pension funds and sovereign wealth funds, respectively (Table 1). This indicates that hedge funds and mutual funds, for instance, are both in the set of shareholders who are strongly driven by financialization concerns (a qualitative attribute), but hedge funds are more active in pressuring portfolio firms to implement downsizing schemes as compared with mutual funds (a quantitative difference). Sovereign wealth funds, on the other hand, are mostly out of this set.

The fsQCA method relies on the use of breakpoints, that is, coding differences along a spectrum, in the assignment of fuzzy sets membership to each single case variable (Table 1). We used the 'continuous' fuzzy-set scale (Ragin, 2008) to calibrate all our variables (except for leverage), based on the theoretical arguments described later. The three major breakpoints along this scale range from being fully in the set (1), undefined as being in or out of the set (0.5) and being fully out of the set (0). For leverage, we use the direct method of calibration, which is a built-in function of the fsQCA software to calibrate interval-scale data (Ragin, 2008; Schneider and Wagemann, 2012). Once the database sheet is uploaded onto the fsQCA software, and leverage is calibrated, the software is used to process the data and generate the causal paths for necessity and sufficiency. Consistency and coverage thresholds are then defined to assess the significance of the results.

The calibration process operationalizes these variables into fuzzy-set membership scores and is detailed in Table 1. First, all cases of workforce reductions are included in our database for the sampled firms during the period under review. Substantial employee downsizing was classified as workforce reductions of 5 per cent or more per annum, which is also in line with previous studies (Ahmadjian and Robbins, 2005; Munoz-Bullon and Sanchez-Bueno, 2014). Our calibration framework thus distinguishes between substantial downsizing cases (where the outcome variable is coded as ' 1 ') and other random reductions in the number of staff. Second, leverage was operationalised as the average of total debts over total capital for our two countries (Bessler et al., 2011). Single country coding of leverage is problematic given the presence of differences in the importance of bank financing among countries (Atanassov and Kim, 2009). Thus, we computed leverage by calculating the average of the total debt to total capital percentages of all sampled companies ( 56 for France and 57 for the UK) for the period under review divided by the number of years, that is, 6 years. Final leverage figures are 48 per cent for France and 40 per cent for the UK, hence an average of 44 per cent. The qualitative breakpoints to code leverage using the direct method of calibration were defined around the average for both countries: cases with leverage percentages of 44 per cent upwards were assigned a fuzzy-set membership of 1 , cases at half this percentage, that is, 22 per cent, were assigned a fuzzy-set membership value of 0.5 while cases with a leverage of 1 per cent were completely out of the set with a membership of 0 (Table 1).

Third, the calibration for ownership structure was taken from Gourevitch and Shinn (2005) and identifies specific thresholds for ownership diffusion (less than 5 per cent) and the presence of an insider owner who can shape the strategy of the company (more than 20 per cent) (Table 1). Fourth, the calibration for investors is based on three criteria that highlight the extent to which they have incorporated shareholder value concerns at the expense of employee interests: financial incentives of fund managers, investment horizons and trading turnover of funds, and the extent to which their investment strategy is driven by performance concerns versus risk diversification (Kahan and Rock, 2007; Gospel and Pendleton, 2014). 


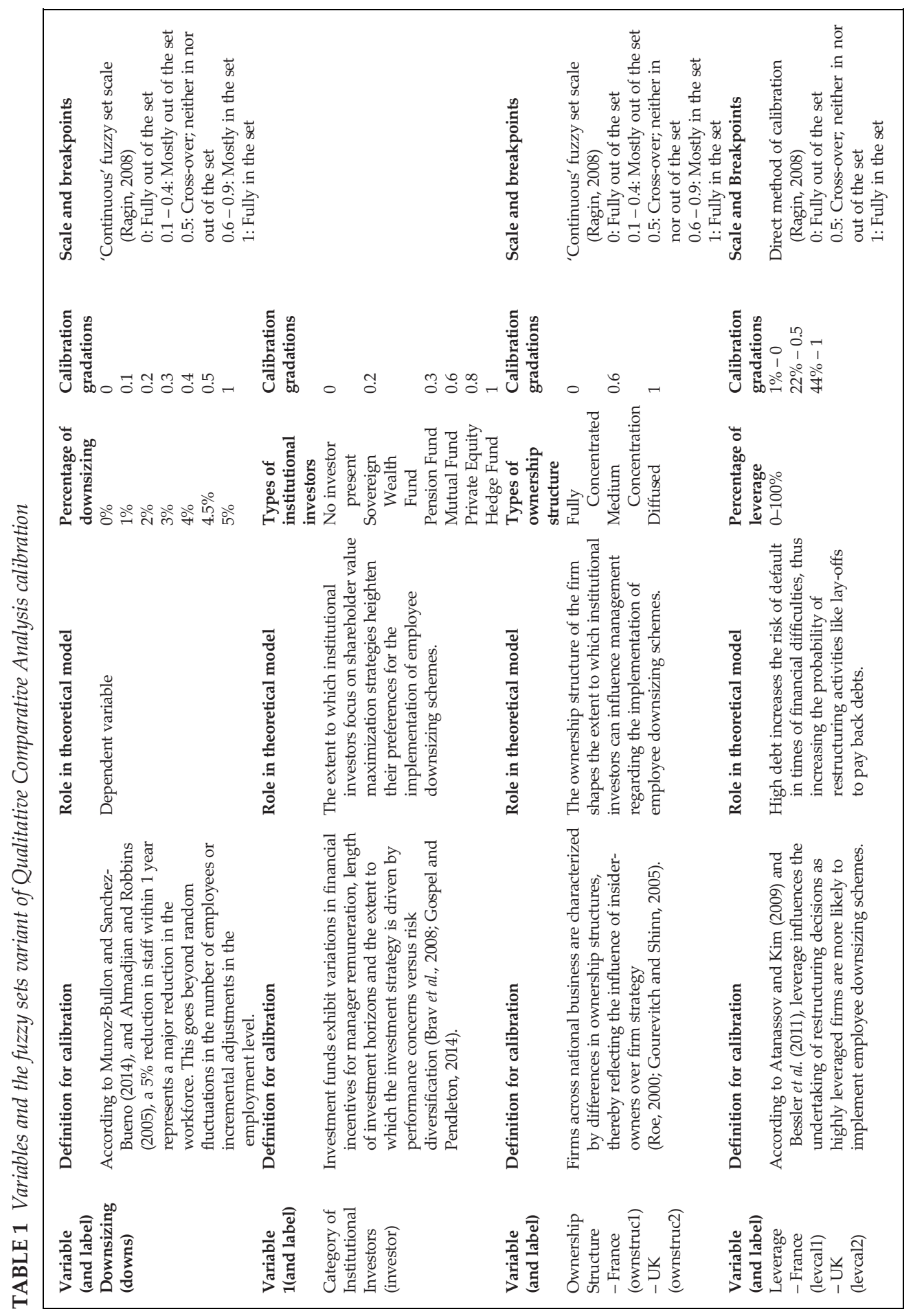




\section{DATA AND SAMPLES}

Our sample comprises the largest stock market capitalization in each country, the SBF120 for France and the FTSE 100 for the UK, as large firms are more likely to be targeted by shareholder value driven investors (Brav et al., 2008). We selected companies that are/were members of either of these two indexes for at least two consecutive years from 2008 to 2013. We excluded financial companies, such as banks and insurance companies, because their leverage ratio and accounting practices are not comparable with non-financial companies (Atanassov and Kim, 2009). We also excluded companies with a dual class of shares that, effectively, provide (potential) equity owners with only non-voting shares. Subsidiaries of foreign companies listed in London or Paris were also excluded. Our final sample is composed of $57 \mathrm{UK}$ companies and 56 French firms. Company information was collected for the period 2008-2013 to assess the impact of the great financial crisis on the undertaking of employee downsizing in different institutional settings. The dependent variable (employee lay-offs) is operationalized as a 5 per cent or more reduction in the number of employees from the previous year (Ahmadjian and Robbins, 2005; Munoz-Bullon and Sanchez-Bueno, 2014). This information was collected from DATASTREAM (2015).

Our three independent variables are measured in the following manner. Drawing from Atanassov and Kim (2009), we used total debts over total capital as a measurement of leverage. The amount of debt carried by companies provides insights on the incentives of corporate executives to secure concessions from employees. This information was also collected from DataStream (2015). Data on ownership structure and the presence of institutional investors were collected as follows. First, data on French companies were collected from annual company reports; from Dafsaliens (2008-2013), an annual publication on the ownership structure of listed companies; and from the database of the French Financial Supervisory Authority that publishes on a daily basis the arrival and exit of major shareholders exceeding current disclosure requirements (3 per cent) in listed companies. Second, data on UK companies were collected from annual reports and from the database of the Financial Times (FT 500, 2015) that provides a full list of past and current shareholders exceeding the disclosure requirements (3 per cent).

\section{FINDINGS}

We highlight the importance of two key QCA concepts before the presentation of our results: consistency and coverage scores (Ragin, 2000). Consistency scores measure the degree to which a combination of causal conditions generates the phenomenon of interest on the dependent variable. That is, will the presence of a combination of conditions lead to the occurrence of the dependent variable? Coverage scores, in contrast, measure the extent to which a causal combination of conditions contributes to the occurrence of the outcome of interest on its own. That is, how much of the occurrence of the dependent variable is generated by the presence of the combination of conditions on the independent variable? High consistency and coverage scores reflect the causal importance of independent variables for generating an outcome (Schneider and Wagemann, 2012).

Our empirical results support our argument that the spread of employee downsizing to France is indeed occurring but is also characterized by an extensive and highly specific process of complex causation, whereas in the UK, the introduction of employee downsizing is more easily implemented. First, employee downsizing is roughly equivalent in the two countries despite the presence of institutional differences. Our sample is composed of 57 UK companies 
and 56 French firms. In the UK, 66 instances of substantial employee downsizing (5 per cent of more in yearly reduction) took place from 2008 to 2013. The corresponding figure for France was 57.

Second, high leverage is identified as a necessary condition in the undertaking of employee downsizing in France with a consistency of 0.92, thus exceeding the advisable threshold of 0.90 for tests of necessity (Schneider and Wagemann, 2012). The coverage value of 0.57 indicates high relevance. In other words, large-scale lay-offs in France occur only in the restrictive context of high leverage for the period under investigation. This is in sharp contrast to the UK and the US where downsizing is often used as a tool to boost share price irrespective of macroeconomic conditions (Farber and Hallock, 2009). This outcome suggests the importance of the constraining institutional arrangements of employment protection in France and is consistent with Proposition 1.

Third, the presence of three variables - high leverage, highly aggressive investors and ownership diffusion - constitutes a sufficient path to trigger employee downsizing in France. The consistency score for this combination of conditions is 0.78 , which is above the minimum threshold of 75 per cent prescribed by Schneider and Wagemann (2012) for tests of sufficiency. In other words, in 78 per cent of the cases where this combination of conditions was present, employee downsizing was high. This solution path also had a coverage value of 0.40 that is in line with previous studies (Greckhamer, 2011; Korczynski and Evans, 2013), meaning that 40 per cent of total instances of downsizing occurred precisely because of this combination of conditions. In other words, the occurrence of employee downsizing in France reflects the presence of a perfect storm of a combination of conditions whereby the absence of any of these factors would remove the sufficient character of this path to employee downsizing. This result is consistent with Propositions $1,3,4$ and 6 .

Fourth, the UK illustrates the presence of significantly less demanding conditions for the implementation of employee downsizing. No necessary conditions were identified for downsizing. With regard to sufficient pathways for downsizing, the most powerful combination of conditions is ownership diffusion combined with the presence of highly aggressive short-term oriented investors, with a consistency value of 0.75 and a coverage value of 0.65 . Empirical results for the UK are consistent with Propositions 2, 3 and 5. These outcomes suggest the greater ability of highly financialized investors (hedge funds and private equity funds) to secure a favourable outcome in the presence of ownership diffusion, that is, in the context whereby no shareholder owns a controlling equity stake. In particular, hedge funds and private equity funds seek to secure significant employee downsizing programmes even in the absence of high leverage.

\section{DISCUSSION AND CONCLUSION}

An important theoretical contribution of this article is that the implementation of employee downsizing schemes is appropriately explained by the integration of two theoretical approaches: structurally based financialization and mid-range institutional perspectives. Structurally oriented financialization approaches significantly contribute to our understanding of employee downsizing by incorporating important developments in the global economy. Financialization approaches have successfully developed a conceptualization of finance beyond its traditional intermediary function. Financialization is not about the provision of funding whether stock market finance (Engelen and Konings, 2010) or banks loans (Hardie 
et al., 2013) as reflected in the selection of our three financialized firm-level variables. Our focus on listed companies illustrates that the rise of shareholder value driven financialized investors, and the growing ownership diffusion of shares, do not bring addition funds to companies because these transactions occurred in the form of secondary trading for already existing securities (Kahan and Rock, 2007; Brav et al., 2008). Leverage, on the other hand, has become more problematic in the context of the credit crunch whereby banks are more reluctant to roll over existing debts and/or provide new loans (Hardie et al., 2013).

Instead, financialization approaches illustrate how the governance of companies is increasingly more about the distribution of resources in society. The widespread, and roughly equivalent use of large-scale lay-offs in France and the UK highlights the importance of structural changes in the global economy despite the presence of institutional diversity. So while institutional arrangements governing employee dismissals beyond liberal market economies have formally remained stable (OECD, 2013), their influence over outcomes has diminished, even in the institutionally constrained setting of France, as a result of how new structural developments that influence strategic bargaining among different actors at firm level. Yet, this new financial environment does not constitute a stable growth trajectory as resources generated by large-scale lay-offs are not reinvested in the company in contrast to institutionalized compromises under Fordism between managers and employees (Clark, 2011; Appelbaum and Batt, 2014).

In terms of mid-range institutional approaches, our investigation highlights the importance of institutions in structuring the diffusion of new practices beyond liberal market economies while also taking issue with a tendency in the literature that reify institutional frameworks. Moving beyond a deterministic understanding of institutions, whereby outcomes are simply 'read off' from the constellation of prevailing institutional arrangements, we highlight two novel contributions that illustrate how similar institutions can lead to different outcomes while, at the same time, retaining the theoretical importance of institutional approaches as mid-range theory. First, the causal influence of (individual) institutional arrangements is contingent upon the specific characteristics of the complex causation settings in which they are embedded. Similar institutions can lead to different outcomes because they can generate the outcome of interest on the dependent variable as part of a specific intersection of necessary but not sufficient conditions or via different but functionally equivalent paths (sufficient but not necessary). For instance, private equity and hedge funds in the UK are able to secure employee downsizing in the presence of ownership diffusion and, moreover, without needing high leverage as a causal factor. In France, in contrast, employee downsizing occurs in the more restrictive context of financialized investors, ownership diffusion and high leverage.

Our second contribution on mid-range institutional approaches illustrates how the use of employee downsizing spreads across different settings via the presence of different types of complex causation. Our argument builds upon a number of studies, especially in economic sociology, that illustrate the importance of the local context (institutional bricolage, institutional legitimacy) for the diffusion of practices beyond their original setting (Campbell, 2004). The innovative aspect of our contribution to this debate suggests that different configurations of institutional arrangements will require different types of complex causation for a common outcome to occur across dissimilar business systems (Goyer, 2011: 106-128). That is, diversity in institutional arrangements accounts for the uneven distribution of necessary/sufficient conditions between cases. By comparing an institutionally constraining setting with a more permissive one, our findings illustrate that more exhaustive sets of factors will be needed in the former in order to generate a functionally equivalent outcome. For instance, the spread of financialization to France, a non-liberal market economy, took place as a result of a confluence 
of two exhaustive factors: leverage as a necessary condition (Proposition 1) and the joint presence of high leverage, financialized investors and ownership diffusion as a sufficient condition (Propositions 1, 3, 4 and 6). In the UK, by contrast, the implementation of downsizing operates independently of leverage (Proposition 2) and, moreover, the less exhaustive configuration of short-term investors and ownership diffusion is sufficient to trigger employee downsizing (Proposition 5).

The managerial implications of our study illustrate that while downsizing pressures associated with financialization are likely to be present beyond liberal market economies, their undertaking is contingent upon a confluence of two or more favourable factors. Managerial strategies based on the use of large-scale lay-offs, such as a focus on core competencies and post-acquisition restructuring, need to incorporate factors that are often part of the background environment in liberal market economies. For instance, permissive institutional arrangements for employee dismissals and the overall preponderance of patterns of ownership diffusion constitute 'constant' variables that are not usually taken into account by managers in liberal market economies in the implementation of employee lay-offs (Brav et al., 2008). It is clear, however, that the extent and depth of these pressures measured across our three criteria is less evident in France than convergence arguments focused on the global diffusion of shareholder capitalism might suggest.

\section{Acknowledgments}

Earlier versions of the article were presented at the 2015 annual meeting of the Council of Europeanists, Paris, and at the Seminar Series, Centre for Sustainable Work and Employment Futures, University of Leicester, 4 March 2015. We thank Ruth Aguilera, Priscilla Alamos-Concha, Rosemary Batt, Steve Bull, Bob Hancké, Peter Jackson, Patrick Mello, Peter Nolan and Carsten Schneider for their comments. The usual disclaimer applies.

\section{Notes}

1. A growing number of scholars are being drawn to Qualitative Comparative Analysis as a methodology to capture processes of complex causation in diverse areas of employment relations such as customer abuse in service sectors (Korczynski and Evans, 2013), job security regulations in Europe (Emmenegger, 2011) and relative pay differences (Greckhamer, 2011).

2. The funding gap of banks is calculated as assets and loans/assets.

\section{REFERENCES}

Ahmadjian, C.L. and Robbins, G.E. (2005). 'A clash of capitalisms: foreign shareholders and corporate restructuring in 1990s Japan'. American Sociological Review, 70: 3, 451-471.

Ahmadjian, C.L. and Robinson, P. (2001). 'Safety in numbers: downsizing and the deinstitutionalization of permanent employment in Japan'. Administrative Science Quarterly, 46: 4, 622-654.

Appelbaum, E. and Batt, R. (2014). Private Equity at Work, New York: Russell Sage Foundation.

Appelbaum, E., Batt, R. and Clark, I. (2013). 'Implications of financial capitalism for employment relations research: evidence from breach of trust and implicit contracts in private equity buyouts'. British Journal of Industrial Relations, 51: 3, 498-518.

Atanassov, J. and Kim, E.H. (2009). 'Labor and corporate governance: international evidence from restructuring decisions'. The Journal of Finance, 64: 1, 341-374.

Bessler, W., Drobetz, W. and Kazemich, R. (2011). 'Factors affecting capital structure', in H. Baker and G. Martin (eds), Capital Structure and Corporate Financing Decisions, Hoboken, NJ: John Wiley \& Sons.

Braumoeller, B.F. (2003). 'Causal complexity and the study of politics'. Political Analysis, 11: 3, 209-233. 
Brav, A., Jiang, W., Partnoy, F. and Thomas, R. (2008). 'Hedge fund activism, corporate governance, and firm performance'. The Journal of Finance, 63: 4, 1729-1775.

Bronars, S.G. and Deere, D.R. (1991). 'The threat of unionization, the use of debt and the preservation of shareholder wealth'. The Quarterly Journal of Economics, 106: 1, 231-254.

Bruslerie, H. and Latrous, I. (2012). 'Ownership structure and debt leverage: empirical test of a trade-off hypothesis on French firms'. Journal of Multinational Financial Management, 22: 4, 111-130.

Campbell, J. (2004). Institutional Change and Globalization, Princeton, NJ: Princeton University Press.

Cascio, W. (1993). 'Downsizing: what do we know? What have learned?'. The Executive, 7: 1, 95-104.

Clark, I. (2009). 'Owners and managers: disconnecting managerial capitalism? understanding the private equity business model'. Work, Employment and Society, 23: 4, 775-786.

Clark, I. (2011). 'Private equity, "union recognition" and value extraction at the AA'. Industrial Relations Journal, 42: 1, 36-50.

Clark, I. (2013). 'Templates for financial control? management and employee under the private equity business model'. Human Resource Management Journal, 23: 2, 144-159.

Dafsaliens (2008-2013). Dafsaliens - La Généalogie Financière, Paris: Dafsaliens.

DataStream (2015). Thomson Reuters DataStream. [Online]. Subscription Service Accessed: June 2014-May 2015.

Datta, D., Guthrie, J., Basuil, D. and Pandley, A. (2010). 'Causes and effects of employee downsizing'. Journal of Management, 36: 1, 281-348.

Davies, P. and Freedland, M. (2007). Towwards a Flexible Labour Market: Labour Legislation and Regulation since the 1990s, Oxford: Oxford University Press.

Dobbin, F. (1994). Forging Industrial Policy: The United States, Britain, and France in the Railway Age, New York: Cambridge University Press.

Emmenegger, P. (2011). 'Job security regulations in Western Europe: a fuzzy set analysis'. European Journal of Political Research, 50: 3, 336-374.

Engelen, E. and Konings, M. (2010). 'Financial capital resurgent: comparative institutionalism and the challenges of financialization', in G. Morgan, J. Campbell, C. Crouch, O.K. Pedersen and R. Whitley (eds), The Oxford Handbook of Comparative Institutional Analysis, Oxford: Oxford University Press.

Farber, H.S. and Hallock, K.F. (2009). 'The changing relationship between job loss announcements and stock prices: 1970-1999'. Labour Economics, 16: 1, 1-11.

Financial Times (2015). FT 500, available at www.ft.com/indepth/ft500. Last Accessed: 22 June, 2015.

Goergen, M., Brewster, C. and Wood, G. (2013). 'The effects of the national setting on employment practice: the case of downsizing'. International Business Review, 22 :6, 1051-1067.

Goergen, M., O'Sullivan, N. and Wood, G. (2014). 'The consequences of private equity acquisitions for employees: new evidence on the impact on wages, employment and productivity'. Human Resource Management Journal, 24: 2, 145-158.

Gospel, H. and Pendleton, A. (2014). 'Financialization, new investment funds and labour', in H. Gospel, A. Pendleton and S. Vitols (eds), Financialization, New Investment Funds and Labour: An International Comparison, Oxford: Oxford University Press.

Gourevitch, P. and Shinn, J. (2005). Political Power and Corporate Control: The New Global Politics of Corporate Governance, Princeton, NJ: Princeton University Press.

Goyer, M. (2006). ‘Varieties of institutional investors and national models of capitalism: the transformation of corporate governance in France and Germany'. Politics and Society, 34: 3, 399-430.

Goyer, M. (2011). Contingent Capital: Short-Term Investors and the Evolution of Corporate Governance in France and Germany, Oxford: Oxford University Press.

Greckhamer, T. (2011). 'Cross-cultural differences in compensation level and inequality across occupation'. Organization Studies, 32: 1, 85-115.

Gumbrell-McCormick, R. and Hyman, R. (2006). 'Embedded collectivism? Workplace representation in France and Germany'. Industrial Relations Journal, 37 :5, 473-491.

Hall, P. (1986). Governing the Economy: The Politics of State Intervention in Britain and France, Oxford: Oxford University Press. 
Hall, P. (2003). 'Aligning ontology and methodology in comparative politics', in J. Mahoney and D. Rueschemeyer (eds), Comparative Historical Analysis in the Social Sciences, New York: Cambridge University Press.

Hardie, I., Howarth, D., Maxfield, S. and Verdun, A. (2013). 'Towards a political economy of banking', in I. Hardie and D. Howarth (eds), Market-based Banking and the International Financial Crisis, Oxford: Oxford University Press.

Howarth, D. (2013). 'France and the international financial crisis'. Governance, 26: 3, 369-395.

Howell, C. (2005). Trade Unions and the State: The Construction of Industrial Relations in Britain, 1890-2000, Princeton, NJ: Princeton University Press.

Jacoby, S. (2005). The Embedded Corporation: Corporate Governance and Employment Relations in Japan and the United States, Princeton, NJ: Princeton University Press.

Kahan, M. and Rock, E. (2007). 'Hedge funds in corporate governance and corporate control'. University of Pennsylvania Law Review, 155: 5, 1021-1093.

Korczynski, M. and Evans, C. (2013). 'Customer abuse to service workers: an analysis of its social creation within the service economy'. Work, Employment and Society, 27: 5, 768-784.

Krippner, G. (2005). 'The financialization of the American economy'. Socio-economic Review, 3: 2, $173-208$.

Mahoney, J. (2004). 'Comparative-historical methodology'. Annual Review of Sociology, 30: 81-101.

Mahoney, J. (2008). 'Toward a united theory of causality'. Comparative Political Studies, 41: 4-5, 412-436.

Munoz-Bullon, F. and Sanchez-Bueno, M. (2014). 'Institutional determinants of downsizing'. Human Resource Management Journal, 24: 1, 111-128.

OECD (2013). OECD Economic Outlook, Paris: OECD.

Ragin, C. (1987). The Comparative Method: Moving Beyond Qualitative and Quantitative Strategies, Berkeley, CA: University of California Press.

Ragin, C. (2000). Fuzzy-set Social Science, Chicago, IL: University of Chicago Press.

Ragin, C. (2008). Redesigning Social Inquiry: Fuzzy Sets and Beyond, Chicago, IL: University of Chicago Press.

Roe, M. (2000). 'Political preconditions to separating ownership from corporate control'. Stanford Law Review, 53: 3, 539-606.

Schneider, C. and Wagemann, C. (2012). Set-theoretic Methods for the Social Sciences, New York: Cambridge University Press.

The Economist (2013), 'Through the looking glass: France may be struggling but its banks are coming good', The Economist, 11 May.

Thelen, K. and Mahoney, J. (2015). 'Comparative-historical analysis in contemporary political science', in J. Mahoney and K. Thelen (eds), Advances in Comparative-historical Analysis, New York: Cambridge University Press.

Thelen, K. and Steinmo, S. (1992). 'Historical institutionalism in comparative politics', in S. Steinmo, K. Thelen and F. Longstreth (eds), Structuring Politics, New York: Cambridge University Press.

Thompson, P. (2011). 'The trouble with HRM'. Human Resource Management Journal, 21: 4, 355-367.

Thompson, P and Cushen, J. (2015). 'Financialization and the workplace: why labour and the labour process still matters', Work, Employment and Society, forthcoming.

van der Zwan, N. (2014). 'State of the art: making sense of financialization'. Socio-economic Review, 12: 1, 99-129.

Venn, D. (2009). Legislation, collective bargaining and enforcement, OECD social employment and migration working paper \#89, Directorate for Employment, Labour and Social Affairs, OECD, Paris.

Whitley, R. (1999). Divergent Capitalisms: The Social Structuring and Change of Business Systems, Oxford: Oxford University Press. 